\title{
Synthesis and pharmacological characterization of potent, selective, and orally bioavailable isoindoline class dipeptidyl peptidase IV inhibitors
}

\author{
Noriyasu Kato ${ }^{1 *}$, Mitsuru Oka', Takayo Murase ${ }^{1}$, Masahiro Yoshida', Masao Sakairi ${ }^{1}$, Mirensha Yakufu, \\ Satoko Yamashita ${ }^{1}$, Yoshika Yasuda ${ }^{1}$, Aya Yoshikawa ${ }^{2}$, Yuji Hayashi $^{1}$, Masahiro Shirai ${ }^{1}$, Yukie Mizuno ${ }^{1}$, \\ Mitsuaki Takeuchi', Mitsuhiro Makino', Motohiro Takeda ${ }^{1}$ and Takuji Kakigami ${ }^{2}$
}

\begin{abstract}
Focused structure-activity relationships of isoindoline class DPP-IV inhibitors have led to the discovery of $\mathbf{4} \mathbf{b}$ as a highly selective, potent inhibitor of DPP-IV. In vivo studies in Wistar/ST rats showed that $\mathbf{4} \mathbf{b}$ was converted into the strongly active metabolite $\mathbf{4} \mathbf{l}$ in high yield, resulting in good in vivo efficacy for antihyperglycemic activity.
\end{abstract}

\section{Background}

With the advent of sitagliptin (MK-0431) and vildagliptin (LAF-237), doubt no longer exists regarding the potential of dipeptidyl peptidase IV (DPP-IV; CD26; E.C. 3.4.14.5) inhibitors for the treatment of type 2 diabetes [1-4]. Hence, intensive research efforts are being continued, and have led to the discovery of a number of potent DPP-IV inhibitors (Figure 1) [5-9]. Research on second-generation DPP-IV inhibitors has focused on selectivity for DPP-IV over other proline-specific dipeptidyl peptidases, especially DPP $8 / 9$, since it has been suggested that inhibition of DDP-8/9 is associated with severe toxicity $[10,11]$. In addition, the results of recent clinical trials have indicated that prolonged and marked inhibition of DPP-IV would be beneficial for severely diabetic patients $[12,13]$. The requirement for prolonged, high exposure in humans imposes stringent requirements on the safety profiles and ADME properties of back-up compounds. In this article, we describe our preliminary results with potent and selective isoindoline class DPP-IV inhibitors with respect to CYP, cytochrome P450, induction, and rodent PK, studies as well as inhibition of DPP-IV activity.

\footnotetext{
* Correspondence: n_katoh@mb4.skk-net.com

'Central Research Laboratory, Sanwa Kagaku Kenkyusho, Co., Ltd., 363

Shiosaki, Hokusei-cho, Inabe-city, Mie 511-0406, Japan

Full list of author information is available at the end of the article
}

\section{Results and discussion}

Very recently, Jiaang and co-workers reported that prolinenitrile-based inhibitors with heterocyclic rings showed high selectivity and potency for DPP-IV as well as in vivo efficacy compared to vildagliptin [14]. We had also pursued the possibility of isoindoline class DDP-IV inhibitors and found their high potency and excellent in vivo efficacy [15]. Thus, isoindolines were synthesized as shown in Figure 1 and evaluated in vitro for their ability to inhibit human recombinant DPP-IV and were also screened for their selectivity over DPP-8/9 by a fluorescence assay using glycyl-proline 7-amino-4-methylcoumarin (H-Gly-Pro-AMC). The inhibitory potency is reported as the $\mathrm{IC}_{50}$ value (Table 1 ). All the compounds had excellent selectivity for DPP-IV over the other related peptidases. Monosubstitution at positions around the benzene ring of $\mathbf{4 a}$ was well tolerated, while retaining a high level of selectivity. Disubstitution, however, led to a slight decrease in potency $(\mathbf{4 j}$, $\mathbf{k})$. Disappointingly, most compounds showed CYP induction of either or both of the two enzymes. Eventually, 4b was subjected to further investigation.

In vivo PK studies on $\mathbf{4 b}$ showed a short plasma halflife and reduced AUC when dosed intravenously (Table 2). Apparently, the reduction in AUC was partly due to a very high clearance. On the other hand, oral administration of $\mathbf{4} \mathbf{b}$ showed an improved half-life and a dosedependent increase in AUC. As it was estimated from the PK profiles that $3-10 \mathrm{mg} / \mathrm{kg}$ doses of $\mathbf{4 b}$ would 


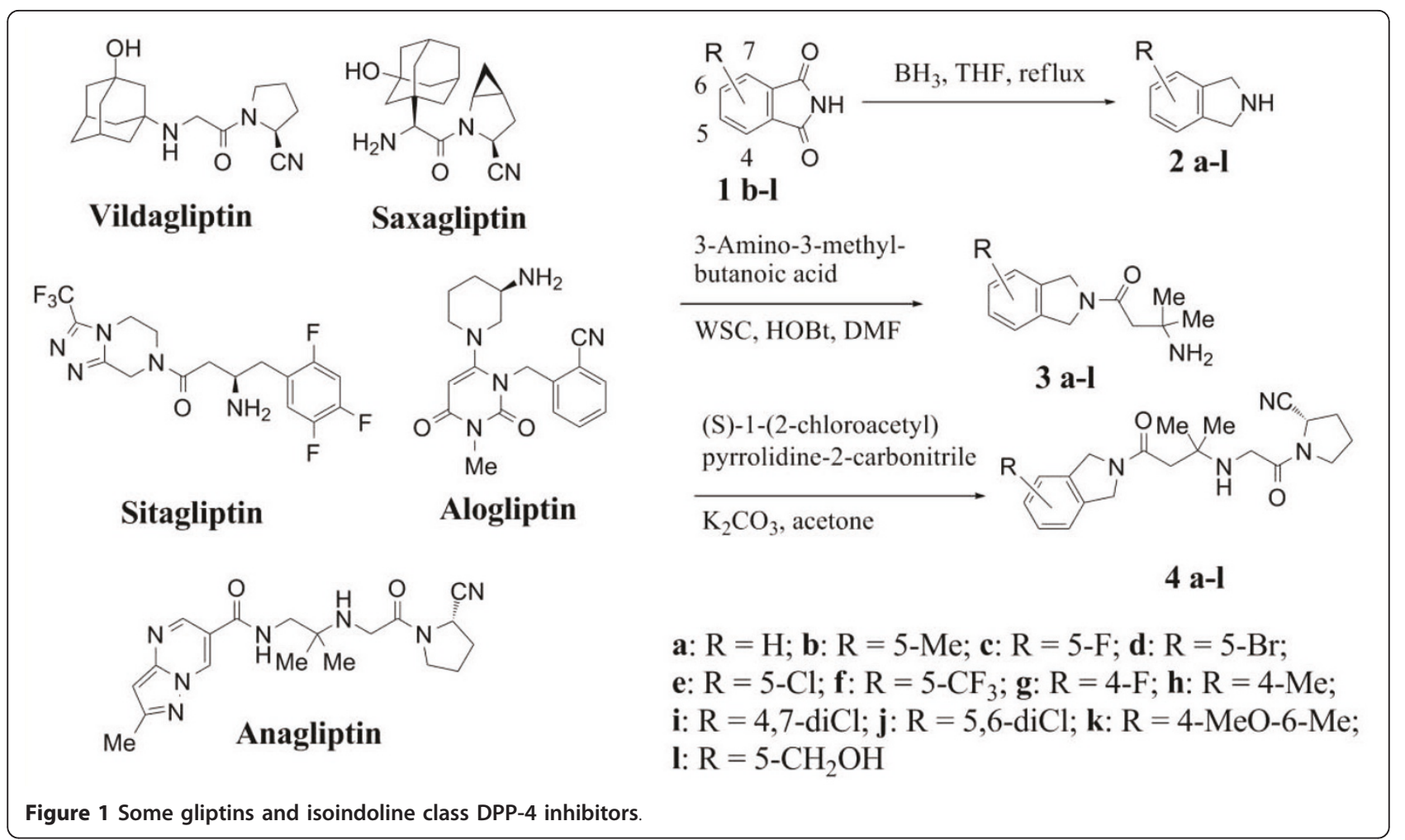

provide $>50 \%$ inhibition of DPP-IV for several hours, we tried to briefly examine the potency of $\mathbf{4 b}$ in oral glucose tolerance tests (OGTT).

Fasted male Wistar/ST rats received either vehicle or 4b at different oral doses (Figure 2). After $30 \mathrm{~min}(t=$ $0)$, oral glucose challenges $(1 \mathrm{~g} / \mathrm{kg})$ were conducted and then plasma DPP-IV activities and blood glucose levels were monitored at various intervals over a $2 \mathrm{~h}$ period.
Selected data are shown in Figure 2. To our surprise, the $1 \mathrm{mg} / \mathrm{kg}$ dose of $\mathbf{4 b}$ resulted in $95 \%$ inhibition of plasma DPP-IV activity within $30 \mathrm{~min}$ post-dose and inhibition of greater than $90 \%$ was maintained throughout the study. The inhibitory effect was dose-dependent, and even the $0.1 \mathrm{mg} / \mathrm{kg}$ dose produced $30 \%$ inhibition. Similarly, reduction of glucose levels paralleled DPP-IV inhibition and a reduction of $18 \%$ was observed at a

Table 1 Inhibition of DPP-IV, -8 and -9 activity by 1,3-dihydroisoindoline derivatives 4, their metabolic clearance by rat and human and their enzyme-inducing (CYP1A, CYP2B, and CYP3A) capacity

\begin{tabular}{|c|c|c|c|c|c|c|c|c|c|}
\hline \multirow[t]{2}{*}{ Compound 4} & \multirow[t]{2}{*}{$\mathbf{R}$} & \multicolumn{3}{|c|}{$\mathrm{IC}_{50}(\mathrm{nM})$} & \multicolumn{2}{|c|}{ CL'int (L/h/Kg) } & \multicolumn{3}{|c|}{ Enzyme induction (rat) } \\
\hline & & DPP-IV & DPP8 & DPP9 & Rat & Human & CYP1A & CYP2B & CYP3A \\
\hline$a$ & $-H$ & 2.3 & $>100,000$ & $>100,000$ & 1.3 & 0.2 & + & + & + \\
\hline b & 5-Me & $3.4(28)^{c}$ & 59,000 & $>100,000$ & 2.3 & 0.1 & - & - & - \\
\hline c & $5-\mathrm{F}$ & 1.9 & $>100,000$ & $>100,000$ & 2.6 & 4.8 & - & + & N.T. ${ }^{b}$ \\
\hline d & $5-\mathrm{Br}$ & 3.0 & 36,000 & $>100,000$ & N.T. ${ }^{b}$ & N.T. ${ }^{b}$ & - & + & N.T. ${ }^{b}$ \\
\hline e & $5-\mathrm{Cl}$ & 4.8 & 44,000 & $>100,000$ & N.T. ${ }^{b}$ & N.T. ${ }^{b}$ & - & + & N.T. ${ }^{b}$ \\
\hline f & $5-\mathrm{CF}_{3}$ & 5.4 & $>100,000$ & $>100,000$ & N.T. ${ }^{b}$ & N.T. ${ }^{b}$ & + & + & N.T. ${ }^{b}$ \\
\hline g & $4-\mathrm{F}$ & 2.6 & $>100,000$ & $>100,000$ & N.T. ${ }^{b}$ & N.T. ${ }^{b}$ & - & + & N.T. ${ }^{b}$ \\
\hline h & 4-Me & 4.0 & $>100,000$ & $>100,000$ & N.T. ${ }^{b}$ & N.T. ${ }^{b}$ & - & + & N.T. ${ }^{b}$ \\
\hline i & $4,7-\mathrm{diCl}$ & 2.6 & $>100,000$ & $>100,000$ & N.T. ${ }^{b}$ & N.T. ${ }^{b}$ & + & - & N.T. ${ }^{b}$ \\
\hline j & 5,6-diCl & 22 & $>100,000$ & 74,000 & N.T. ${ }^{b}$ & N.T. ${ }^{b}$ & + & + & N.T. ${ }^{b}$ \\
\hline k & 4-MeO-6-Me & 16 & $>100,000$ & $>100,000$ & N.T. ${ }^{b}$ & N.T. ${ }^{b}$ & - & + & N.T. ${ }^{b}$ \\
\hline 1 & $5-\mathrm{CH}_{2} \mathrm{OH}$ & $1.9^{\mathrm{a}}$ & N.T. & N.T. & N.T. ${ }^{b}$ & N.T. ${ }^{b}$ & - & - & N.T. ${ }^{b}$ \\
\hline
\end{tabular}

${ }^{\mathrm{a}} \mathrm{C}_{50}$ determined with respect to human plasma DPP-IV in separate experiments.

${ }^{\mathrm{b}}$ Not tested. 
Table 2 PK parameters of $4 b$ in SD rats

\begin{tabular}{|c|c|c|c|c|c|c|c|c|c|}
\hline Route & $\begin{array}{l}\text { Dose } \\
(\mathrm{mg} / \mathrm{kg})\end{array}$ & $\begin{array}{l}t_{1 / 2 \alpha} \\
\text { (h) }\end{array}$ & $\begin{array}{l}t_{1 / 2 \alpha} \\
\text { (h) }\end{array}$ & $\begin{array}{l}\mathrm{Vd}_{\mathrm{ss}} \\
(\mathrm{L} / \mathrm{kg})\end{array}$ & $\begin{array}{l}\mathrm{CL}_{\mathrm{p}} \\
(\mathrm{L} / \mathrm{h} / \mathrm{kg})\end{array}$ & $\begin{array}{l}\mathrm{C}_{\max } \\
(\mathrm{ng} / \mathrm{mL})\end{array}$ & $\begin{array}{l}T_{\max } \\
\text { (h) }\end{array}$ & $\begin{array}{l}A_{U U C} C_{0-9 h} \\
(\mathrm{ng} \mathrm{h} / \mathrm{mL})\end{array}$ & $\begin{array}{l}\text { BA } \\
\text { (\%) }\end{array}$ \\
\hline IV & 1 & 0.062 & 0.27 & 8.28 & 26.2 & ND & ND & 39 & \\
\hline \multirow[t]{2}{*}{ po } & 3 & ND & 1.37 & ND & ND & 37 & 0.25 & 33 & 27.7 \\
\hline & 10 & ND & 1.50 & ND & ND & 229 & 0.25 & 156 & 39.9 \\
\hline
\end{tabular}

dose of $1 \mathrm{mg} / \mathrm{kg}$. In addition, increased insulin levels at $10 \mathrm{~min}$ post-challenge strongly suggested preservation of active GLP-1.

The high clearance of $\mathbf{4 b}$ suggested that the unexpected in vivo efficacy might be explained by the presence of active metabolites. Therefore, further PK studies were conducted. A major metabolite was detected by LC-MS analysis and its structure was determined by comparison of the LC retention time and MS/MS fragmentation pattern with synthetic standards. Consequently, 41 was identified as a very active metabolite, which showed a reasonable degree of systemic exposure by virtue of in vivo conversion as high as $60 \%$.

\section{Conclusions}

In summary, the focused, small SARs of the isoindoline derivatives have led to the discovery of $\mathbf{4 b}$ as a highly selective, potent inhibitor of DPP-IV. The in vivo studies showed that the active metabolite 41 had a very high inhibitory potency with respect to DPP-IV. Consequently, we abandoned further development of compounds in this series. However, on the basis of the results described here, we found anagliptin, which has advanced into PIII trials, to have improved safety profiles and PK parameters. This article is also intended to provide information on the scope and limitations of isoindoline-based DPP-IV inhibitors and to facilitate research on the new generation DPP-IV inhibitors.

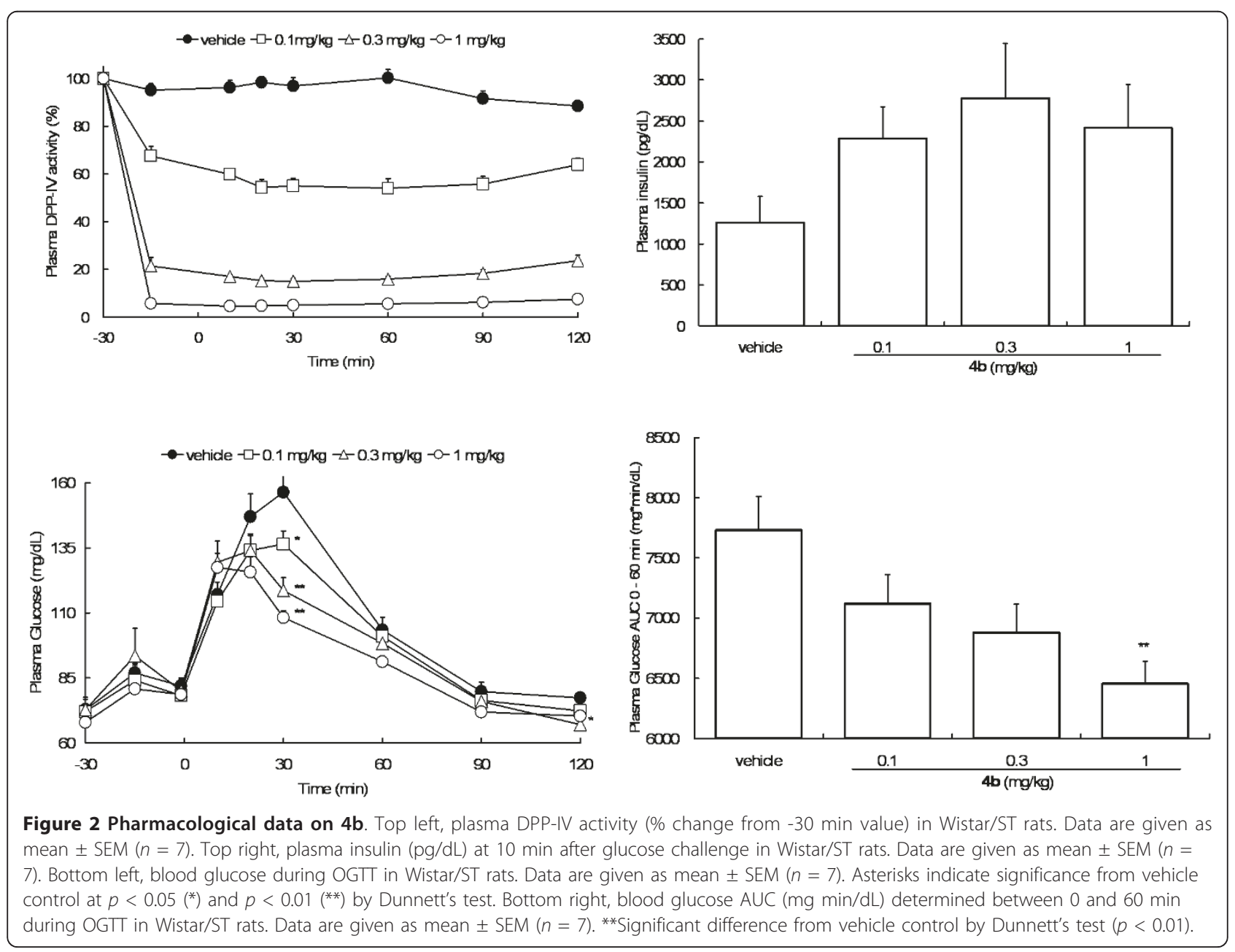




\section{Methods}

\subsection{Compound synthesis}

\subsubsection{General}

All commercially available reagents and solvents were used as-received. All reactions were carried out using oven-dried flasks or glassware, and mixtures were stirred with stirring bars and concentrated using a standard rotary evaporator unless otherwise noted. Procedures for preparation of all intermediates $\mathbf{2}$ and $\mathbf{3}$ were described previously [15]. The ${ }^{1} \mathrm{H}$ NMR spectra were recorded by a JEOL JNM-ECP400 spectrometer operating at $400 \mathrm{MHz}$ in DMSO- $\mathrm{d}_{6}$ at $25^{\circ} \mathrm{C}$ with tetramethylsilane as the internal standard. The data are reported as follows: chemical shift in $\mathrm{ppm}(\delta)$, integration, multiplicity $(\mathrm{s}=$ singlet, $\mathrm{d}=$ doublet, $\mathrm{t}=$ triplet, $\mathrm{q}$ = quartet, $\mathrm{br}=$ broad singlet, $\mathrm{m}=$ multiplet), and coupling constant $(\mathrm{Hz})$. LC/MS spectra were determined on a Waters ZMD2000 equipped with a Waters 2690 injector and a PDA detector operating at 210-400 nm and interfaced with a Micromass ZMD mass spectrometer.

4.1.2. Representative procedure for preparation of pyrrolidine carbonitrile 4; (S)-1-(2-(4-(Isoindolin-2-yl)-2methyl-4-oxobutan-2-ylamino)acetyl)pyrrolidine-2carbonitrile $\mathrm{HCl}$ Salt (4a)

A solution of (S)-1-(2-chloroacetyl)pyrrolidine-2-carbonitrile $(467 \mathrm{mg}, 2.70 \mathrm{mmol})$ in acetone $(5.0 \mathrm{~mL})$ was added drop-by-drop to an ice-cooled stirred suspension of $3 \mathrm{a}(550 \mathrm{mg}, 2.50 \mathrm{mmol}), \mathrm{K}_{2} \mathrm{CO}_{3}(370 \mathrm{mg}, 2.70$ $\mathrm{mmol}$ ), and $\mathrm{NaI}(200 \mathrm{mg}, 1.30 \mathrm{mmol})$ in acetone $(20$ $\mathrm{mL}$ ). The reaction mixture was stirred at room temperature overnight. The resulting mixture was filtered to remove insoluble materials, and concentrated under reduced pressure. The residue was purified by column chromatography on silica gel $\left(\mathrm{CH}_{2} \mathrm{Cl}_{2} / \mathrm{MeOH}=20 / 1\right)$ to give $540 \mathrm{mg}(61 \%)$ of $\mathbf{4 a}$ of the free base. To an icecooled solution of $\mathbf{4 a}$ of the free base $(250 \mathrm{mg}, 0.70$ $\mathrm{mmol})$, 1,4-dioxane $(5.0 \mathrm{~mL})$ was added $4 \mathrm{~N}-\mathrm{HCl} / 1,4$ dioxane $(180 \mu \mathrm{L}, 0.72 \mathrm{mmol})$. The reaction mixture was stirred at $0^{\circ} \mathrm{C}$ for $1 \mathrm{~h}$ and then evaporated to yield the title compound (240 mg, Y. 88\%). ${ }^{1} \mathrm{H}$ NMR $1.38(6 \mathrm{H}, \mathrm{s})$, 2.00-2.22 (4H, m), 2.85-2.90 (2H, m), 3.30-4.10 (4H, m), 4.69 (2H, s), 4.87 (2H, s), 4.80-4.85 (1H, m), 7.25-7.40 $(4 \mathrm{H}, \mathrm{m}) ; \mathrm{MS} m / z 355(\mathrm{M}+\mathrm{H})^{+}$.

4.1.3. (S)-1-(2-(2-Methyl-4-(5-methylisoindolin-2-yl)-4oxobutan-2-ylamino)acetyl)pyrrolidine-2-carbonitrile $\mathrm{HCl}$ Salt (4b)

Colorless solid (92\%). ${ }^{1} \mathrm{H}$ NMR 1.41 (6H, s), 1.99-2.11 (2H, m), 2.18-2.24 (2H, m), 2,32 (3H, s), 2.88-2.98 $(2 \mathrm{H}, \mathrm{m}), 3.21-3.39(2 \mathrm{H}, \mathrm{m}), 3.50-3.57(1 \mathrm{H}, \mathrm{m}), 3.68-$ $3.72(1 \mathrm{H}, \mathrm{m}), 4.06-4.10(1 \mathrm{H}, \mathrm{m}), 4.66(2 \mathrm{H}, \mathrm{s}), 4.86$ (2H, sm), 7.13-7.28 (3H, m), 9.29 (2H, brs); MS $m / z$ $369(\mathrm{M}+\mathrm{H})^{+}$.
4.1.4. (S)-1-(2-(4-(5-Fluoroisoindolin-2-yl)-2-methyl-4oxobutan-2-ylamino)acetyl)pyrrolidine-2-carbonitrile $\mathrm{HCl}$ Salt (4c)

Colorless solid (31\%). ${ }^{1} \mathrm{H}$ NMR $1.40(6 \mathrm{H}, \mathrm{s}), 2.02-2.08$ (2H, m), 2.19-2.22 (2H, m), 2.88-2.89 (2H, m), 3.50-3.69 $(2 \mathrm{H}, \mathrm{m}), 4.04-4.07(2 \mathrm{H}, \mathrm{m}), 4.67-4.70(2 \mathrm{H}, \mathrm{m}), 4.85-4.89$ $(3 \mathrm{H}, \mathrm{m}), 7.16(1 \mathrm{H}, \mathrm{t}, J=9.2 \mathrm{~Hz}), 7.24(1 \mathrm{H}, \mathrm{t}, J=9.2$ $\mathrm{Hz})$, 7.37-7.44 (1H, m), 9.10 (2H, brs); MS $m / z 373$ (M $+\mathrm{H})^{+}$.

4.1.5. (S)-1-(2-(4-(5-Bromoisoindolin-2-yl)-2-methyl-4oxobutan-2-ylamino)acetyl)pyrrolidine-2-carbonitrile $\mathrm{HCl}$ Salt (4d)

Colorless solid (81\%). ${ }^{1} \mathrm{H}$ NMR 1.35 (6H, s), 1.95-2.05 $(2 \mathrm{H}, \mathrm{m}), 2.12-2.18(2 \mathrm{H}, \mathrm{m}), 2.83(2 \mathrm{H}, \mathrm{s}) 3.70-4.05(4 \mathrm{H}$, $\mathrm{m})$, 4.62-4.72 (2H, m), 4.78-4.84 (3H, m), 7.29-7.60 (3H, $\mathrm{m}), 8.21$ (2H, brs); MS $m / z 423(\mathrm{M}+\mathrm{H})^{+}$.

4.1.6. (S)-1-(2-(4-(5-Chloroisoindolin-2-yl)-2-methyl-4oxobutan-2-ylamino)acetyl)pyrrolidine-2-carbonitrile $\mathrm{HCl}$ salt (4e)

Colorless solid (38\%). ${ }^{1} \mathrm{H}$ NMR 1.65 (6H, s), 2.20-2.35 (4H, m), 2.90-3.35 (2H, m), 3.70-4.40 (4H, m), 4.75-5.00 (5H, m), 7.20-7.30 (3H, m); MS m/z $389(\mathrm{M}+\mathrm{H})^{+}$.

4.1.7. (S)-1-(2-(2-Methyl-4-oxo-4-(5-(trifluoromethyl) isoindolin-2-yl)butan-2-ylamino)acetyl)pyrrolidine-2carbonitrile $\mathrm{HCl}$ salt (4f)

Colorless solid (37\%). ${ }^{1} \mathrm{H}$ NMR 1.41 (6H, s), 1.98-2.09 $(2 \mathrm{H}, \mathrm{m}), 2.18-2.25(2 \mathrm{H}, \mathrm{m}), 2.92(2 \mathrm{H}, \mathrm{d}, J=3.3 \mathrm{~Hz})$, 3.50-3.54 (1H, m), 3.67-3.72 (1H, m), 4.00-4.13 (2H, m), $4.78(2 \mathrm{H}, \mathrm{s}), 4.87(1 \mathrm{H}, \mathrm{dd}, J=3.3$ and $7.3 \mathrm{~Hz}), 4.97(2 \mathrm{H}$, s), 7.59-7.64 $(1 \mathrm{H}, \mathrm{m}), 7.69(1 \mathrm{H}, \mathrm{d}, J=8.1 \mathrm{~Hz}), 7.76-7.80$ $(1 \mathrm{H}, \mathrm{m}), 9.19(2 \mathrm{H}, \mathrm{brs}) ; \mathrm{MS} m / z 423(\mathrm{M}+\mathrm{H})^{+}$.

4.1.8. (S)-1-(2-(4-(4-Fluoroisoindolin-2-yl)-2-methyl-4oxobutan-2-ylamino)acetyl)pyrrolidine-2-carbonitrile $\mathrm{HCl}$ salt (4g)

Colorless solid (23\%). ${ }^{1} \mathrm{H}$ NMR 1.40 (6H, s), 2.01-2.09 (2H, m), 2.18-2.25 (2H, m), 2.92-2.94 (2H, m), 3.51-3.53 $(1 \mathrm{H}, \mathrm{m}), 3.66-3.72(1 \mathrm{H}, \mathrm{m}), 4.00-4.13(2 \mathrm{H}, \mathrm{m}), 4.75(2 \mathrm{H}$, s), $4.85-4.87(1 \mathrm{H}, \mathrm{m}), 4.97(1 \mathrm{H}, \mathrm{s}), 7.16(1 \mathrm{H}, \mathrm{t}, J=8.8$ $\mathrm{Hz}), 7.21-7.25(1 \mathrm{H}, \mathrm{m}), 7.37-7.43(1 \mathrm{H}, \mathrm{m}), 9.18(2 \mathrm{H}$, brs); MS $m / z 373(\mathrm{M}+\mathrm{H})^{+}$.

4.1.9. (S)-1-(2-(2-Methyl-4-(4-methylisoindolin-2-yl)-4oxobutan-2-ylamino)acetyl)pyrrolidine-2-carbonitrile $\mathrm{HCl}$ salt (4h)

Colorless solid (33\%). ${ }^{1} \mathrm{H}$ NMR 1.41 (6H, s), 2.03-2.11 $(2 \mathrm{H}, \mathrm{m}), 2.17-2.24(2 \mathrm{H}, \mathrm{m}), 2.26(3 \mathrm{H}, \mathrm{s}), 2.95(2 \mathrm{H}, \mathrm{d}, J=$ $8.9 \mathrm{~Hz}),(2 \mathrm{H}, \mathrm{m}), 3.40-3.66(2 \mathrm{H}, \mathrm{m}), 3.97-4.10(2 \mathrm{H}, \mathrm{m})$, 4.25-4.31 (1H, m), $4.68(2 \mathrm{H}, \mathrm{s}), 4.88(2 \mathrm{H}, \mathrm{s}), 7.11-7.25$ $(3 \mathrm{H}, \mathrm{m}), 9.29(2 \mathrm{H}, \mathrm{brs}) ; \mathrm{MS} m / z 369(\mathrm{M}+\mathrm{H})^{+}$. 4.1.10. (S)-1-(2-(4-(4,7-Dichloroisoindolin-2-yl)-2-methyl-4oxobutan-2-ylamino)acetyl)pyrrolidine-2-carbonitrile $\mathrm{HCl}$ salt (4i)

Colorless solid (69\%). ${ }^{1} \mathrm{H}$ NMR $1.41(6 \mathrm{H}, \mathrm{s}), 2.03-2.10$ (2H, m), 2.19-2.25 (2H, m), 2.94-2.97 (2H, m), 3.67-3.72 
$(2 \mathrm{H}, \mathrm{m}), 4.03-4.14(2 \mathrm{H}, \mathrm{m}), 4.77(2 \mathrm{H}, \mathrm{s}), 4.86(1 \mathrm{H}, \mathrm{dd}, J=$ 4.4 and $7.3 \mathrm{~Hz}), 5.00(2 \mathrm{H}, \mathrm{s}), 7.48(2 \mathrm{H}, \mathrm{s}), 9.18$ (2H, brs); MS $m / z 423(\mathrm{M}+\mathrm{H})^{+}$.

4.1.11. (S)-1-(2-(4-(5,6-Dichloroisoindolin-2-yl)-2-methyl-4oxobutan-2-ylamino)acetyl)pyrrolidine-2-carbonitrile $\mathrm{HCl}$ salt (4j)

Colorless solid (10\%). ${ }^{1} \mathrm{H}$ NMR 1.65 (6H, s), 2.20-2.35 (4H, m), 2.90-3.35 (2H, m), 3.70-4.40 (4H, m), 4.80-4.95 (5H, m), 7.37-7.44 (2H, m); MS m/z $423(\mathrm{M}+\mathrm{H})^{+}$.

4.1.12. (S)-1-(2-(4-(4-Methoxy-6-methylisoindolin-2-yl)-2methyl-4-oxobutan-2-ylamino)acetyl)pyrrolidine-2carbonitrile $\mathrm{HCl}$ salt (4k)

Colorless solid (77\%). ${ }^{1} \mathrm{H}$ NMR $1.55-1.70$ (6H, m), 2.202.35 (4H, m), 2.37 (3H, s), 2.80-3.40 (2H, m), 3.60-4.45 $(7 \mathrm{H}, \mathrm{m}), 4.65-4.90(5 \mathrm{H}, \mathrm{m}), 6.55-6.75(2 \mathrm{H}, \mathrm{m}) ; \mathrm{MS} \mathrm{m} / z$ $399(\mathrm{M}+\mathrm{H})^{+}$.

4.1.13. (S)-1-(2-(4-(5-(Hydroxymethyl)isoindolin-2-yl)-2methyl-4-oxobutan-2-ylamino)acetyl)pyrrolidine-2carbonitrile $\mathrm{HCl}$ salt (4I)

Colorless solid (81\%). ${ }^{1} \mathrm{H}$ NMR 1.41 (6H, s), 2.0-2.25 (4H, m), $2.92(2 \mathrm{H}, \mathrm{m}), 3.5-4.1(4 \mathrm{H}, \mathrm{m}), 4.5-4.9(7 \mathrm{H}, \mathrm{m})$, 7.2-7.4 (3H, m), 9.28 (2H, brs); MS m/z $385(\mathrm{M}+\mathrm{H})^{+}$.

\subsection{Biological evaluation}

\subsubsection{In vitro assay for DPP-IV inhibition}

Inhibition of DPP-IV activity was determined by measuring the rate of hydrolysis of a surrogate substrate, $\mathrm{H}$ Gly-Pro-7-amino-4-methylcoumarin (H-Gly-Pro-AMC). Human recombinant DPP-IV was purchased from R\&D Systems, Minneapolis, MN. $10 \mu \mathrm{L}$ of appropriately diluted solutions of the test compounds in water was added to 96-well microtiter plates, followed by the addition of $40 \mu \mathrm{L}$ of DPP-IV diluted in assay buffer $(25 \mathrm{mM}$ HEPES, $140 \mathrm{mM} \mathrm{NaC1}, 0.1 \mathrm{mg} / \mathrm{mL}$ BSA, pH 7.8). After a 30-min preincubation at room temperature, the reaction was initiated by the addition of $50 \mu \mathrm{L}$ of the assay buffer containing $0.2 \mathrm{mM}$ H-Gly-Pro-AMC. After incubation at room temperature for $20 \mathrm{~min}$, the reaction was stopped by the addition of $100 \mu \mathrm{L}$ of $25 \%$ aqueous acetic acid and fluorescence was measured using an excitation wavelength of $390 \mathrm{~nm}$ and an emission wavelength of $460 \mathrm{~nm}$. A standard curve for AMC was generated by adding $0.2-20 \mu \mathrm{mol}$ of $\mathrm{AMC}$ to buffer solutions containing $12.5 \%$ aqueous acetic acid. The inhibitory rate relative to the control without inhibitor was calculated and $\mathrm{IC}_{50}$ values were determined by nonlinear regression (GraphPad Prism 4, ver. 4.03 software). 4.2.2 In vitro assays for inhibition of DPP-8 and DPP-9

Human DPP-8 and DPP-9 were expressed in baculovirus-infected Sf9 insect cells and purified using Histagged protein purification resins. Inhibition of DPP-8 and -9 activities was determined as described above. 10 $\mu \mathrm{L}$ of appropriately diluted aqueous solutions of the test compounds was added to 96-well microtiter plates, followed by the addition of $50 \mu \mathrm{L}$ of $1.0 \mathrm{mM} \mathrm{H}$-GlyPro-AMC in buffer solution (50 mM HEPES, $0.1 \mathrm{mg} /$ $\mathrm{mL}$ BSA, $\mathrm{pH} 8.0$ ). The reaction was initiated by the addition of $40 \mu \mathrm{L}$ of the enzyme solution diluted in the assay buffer. After incubation at room temperature for $30 \mathrm{~min}$, the reaction was stopped by the addition of 100 $\mu \mathrm{L}$ of $25 \%$ aqueous acetic acid and fluorescence was measured using an excitation wavelength of $390 \mathrm{~nm}$ and an emission wavelength of $460 \mathrm{~nm}$.

\subsubsection{In vivo assay methods}

All procedures were approved by the Sanwa Kagaku Kenkyusho Institutional Animal Care and Use Committee. 7-week old Wistar/ST rats were housed under standard conditions and allowed free access to water and a commercial diet for at least 5 days. The rats were fasted overnight prior to dosing and then received $\mathbf{4 b}$ orally at doses of $0.1-1 \mathrm{mg} / \mathrm{kg}$ or vehicle as a $5 \mathrm{~mL} / \mathrm{kg}$ aqueous solution $30 \mathrm{~min}$ before glucose challenge. After an oral glucose challenge $(5 \mathrm{~mL} / \mathrm{kg}$ of an aqueous solution of $20 \%$ glucose), blood samples were collected from the tail vein of each animal into heparin-containing tubes at serial time points for $2 \mathrm{~h}$. Plasma was prepared immediately, frozen, and stored at $-20^{\circ} \mathrm{C}$ prior to analysis.

\subsubsection{Inhibition of rat plasma DPP-IV ex vivo}

Plasma DPP-IV activity was determined as described above. A $20 \mu \mathrm{L}$ plasma sample was mixed with $5 \mu \mathrm{L}$ of reaction buffer $(140 \mathrm{mM} \mathrm{NaCl}$, and $10 \mathrm{mM} \mathrm{KCl}, 25$ $\mathrm{mM}$ Tris- $\mathrm{HCl}, \mathrm{pH} 7.4,1 \%$ bovine serum albumin) and $10 \mu \mathrm{L}$ of buffer containing $60 \mu \mathrm{M} \mathrm{H}$-Gly-Pro-AMC. After incubation at room temperature for $30 \mathrm{~min}$, the reaction was stopped by the addition of $20 \mu \mathrm{L}$ of $25 \%$ aqueous acetic acid and fluorescence was measured using an excitation wavelength of $360 \mathrm{~nm}$ and an emission wavelength of $460 \mathrm{~nm}$.

\subsubsection{Measurement of plasma glucose and insulin \\ concentrations}

Plasma glucose and insulin were determined with a glucometer (Glutest Pro; SKK, Japan) and a rat insulin ELISA kit (Shibayagi, Japan), respectively, according to the manufacturer's instructions. Statistical analyses were performed using Microsoft Excel. Individual comparisons among more than two experimental groups were assessed using ANOVA, with Fisher's Least Significant Difference post hoc test. Differences were considered significant at $P$ values $<0.05$. Analysis of dose-response data was performed by Dunnett's test.

\subsubsection{Pharmacokinetics (PK) in rats}

Sprague-Dawley (SD) rats were housed under standard conditions and allowed free access to water and a commercial diet. On the day before the experiment, rats were fasted overnight and for the first $12 \mathrm{~h}$ of the experiment. Compounds $\mathbf{4 b}$ were prepared in a saline/ ethanol vehicle $(50 / 50 \mathrm{v} / \mathrm{v})$ at appropriate concentrations of $\mathbf{4 b}$ as an intravenous (iv) injection of $1 \mathrm{~mL} / \mathrm{kg}$ via the 
femoral vein and as a suspension in 5\% gum arabic solution for oral (po) administration. Blood samples were collected from the jugular vein of each animal with a heparinized syringe under diethyl ether anesthesia at serial time points for $24 \mathrm{~h}$ after drug administration. Plasma was obtained by centrifugation at $4^{\circ} \mathrm{C}$ and stored at $-70^{\circ} \mathrm{C}$ until analysis. Protein precipitation was carried out by the addition of the internal standard solution (70\% $\mathrm{CH}_{3} \mathrm{CN}$ with $0.2 \%$ acetic acid) to samples. The tubes underwent vigorous shaking and centrifugation for $5 \mathrm{~min}$; then the supernatant was subjected to LC/MS/ MS analysis. Peak areas were determined using Xcalibur $^{\circledR}$ software (Thermo Electron Corporation, UK) and AUC values were calculated by the trapezoidal rule.

\subsection{Metabolic stability}

The incubation mixture containing $0.25 \mathrm{mg}$ of rat or human liver microsomes was preincubated with an $\mathrm{NADPH}$-generating system for $5 \mathrm{~min}$ at $37^{\circ} \mathrm{C}$. The reaction was started by the addition of $5 \mu \mathrm{L}$ of a DMSO solution containing the test compound $(5 \mu \mathrm{M})$. At $t=0$ and at two additional time points between 0 and 30 min, aliquots $(100 \mu \mathrm{L})$ were removed and added to termination mixtures $\left(\mathrm{CH}_{3} \mathrm{CN}\right)$. Proteins were sedimented by centrifugation and an aliquot of the supernatant was analyzed by LC/MS/MS.

In determinations of the in vitrot t $_{1 / 2}$, the analyte/ISTD peak area ratio was converted to percentage of drug remaining by assigning a value of $100 \%$ to the peak area ratio at $t=0$. The slope of the regression line fitted to the log (percentage remaining) versus incubation time relationship $(-k)$ was used in the conversion of raw data to the in vitrot ${ }_{1 / 2}$ value. In vitro $\mathrm{CL}_{\text {int }}$ was calculated using the following formula.

$$
\mathrm{CL}_{\text {int }}=\frac{0.693}{\text { In vitro } \mathrm{t}_{1 / 2}} \times \frac{\mathrm{mL} \text { incubation }}{\mathrm{mg} \text { microsomes }} \times \frac{45 \mathrm{mg} \text { microsomes }}{\mathrm{mg} \text { liver }} \times \frac{20 \mathrm{mg} \text { liver }}{\mathrm{kg} \text { (b.w.) }}
$$

Enzyme induction was evaluated as follows: Hepatocytes isolated from male SD rats were maintained in culture for 1 day before treatment with the test compound or P-450 inducers. The cells were treated with the test compound $(1,10,50 \mu \mathrm{M}), \beta$-naphthoflavone (10 $\mu \mathrm{M}, \mathrm{CYP} 1 \mathrm{~A}$ inducer), phenobarbital $(50 \mu \mathrm{M}, \mathrm{CYP} 2 \mathrm{~B}$ inducer), dexamethasone (10 $\mu \mathrm{M}, \mathrm{CYP} 3 \mathrm{~A}$ inducer $)$, or vehicle $(0.1 \%$ DMSO final volume; used as negative control) for 2 days.

Induction of CYP1A, CYP2B, and CYP3A enzymes was determined based on measurements of 7-ethoxyresorufin O-dealkylation, 7-pentoxyresorufin O-dealkylation, and testosterone $6 \beta$-hydroxylation, respectively. Assays were started by the addition of Krebs-Henseleit buffer containing $8 \mu \mathrm{M}$ 7-ethoxyresorufin, $10 \mu \mathrm{M}$ 7-pentoxyresorufin, or $250 \mu \mathrm{M}$ testosterone at a volume of $100 \mu \mathrm{L}$ per well. After incubation at $37^{\circ} \mathrm{C}$ for $30 \mathrm{~min}$, aliquots were removed and analyzed by fluorometry (an excitation wavelength of $538 \mathrm{~nm}$ and an emission wavelength of $590 \mathrm{~nm}$ ) or LC/MS/MS to determine the quantities of metabolites formed. Any test compound causing a dose-dependent change equal to or greater than $10 \%$ of the positive control (see formula below) was considered an enzyme inducer. $\%$ positive control $=\frac{\text { (activity of test }- \text { compound treated cells }- \text { activity of negative control) }}{\text { (activity of positive control }- \text { activity of negative control) }} \times 100$

\section{Author details}

${ }^{1}$ Central Research Laboratory, Sanwa Kagaku Kenkyusho, Co., Ltd., 363 Shiosaki, Hokusei-cho, Inabe-city, Mie 511-0406, Japan ²Sanwa Kagaku Kenkyusho, Co., Ltd., 35 Higashisotobori-cho, Higashi-ku, Nagoya 461-8631, Japan ${ }^{3}$ Xinjiang Medical University, Urumqi 830011, China

\section{Competing interests}

The authors declare that they have no competing interests.

Received: 22 June 2011 Accepted: 12 September 2011 Published: 12 September 2011

\section{References}

1. Ahre'n B (2007) Dipeptidyl peptidase-4 inhibitors: clinical data and clinical implications. Diabetes Care 30(5):1344-1350

2. Aschner P, Kipnes MS, Lunceford JK, Sanchez M, Mickel C, WilliamsHerman ED (2006) Effect of the Dipeptidyl peptidase-4 inhibitor sitagliptin as monotherapy on glycemic control in patients with type 2 diabetes. Diabetes Care 29(12):2632-2637. doi:10.2337/dc06-0703.

3. Bosi E, Camisasca RP, Collober C, Rochotte E, Garber AJ (2007) Effects of vildagliptin on glucose control over 24 weeks in patients with type 2 diabetes inadequately controlled with metformin. Diabetes Care 30(4):890-895. doi:10.2337/dc06-1732.

4. Rosenstock J, Barron MA, Dejager S, Mills D, Schweizer A (2007) Comparison of vildagliptin and rosiglitazone monotherapy in patients with type 2 diabetes: a 24-week, double-blind, randomized trial. Diabetes Care 30(2):217-223. doi:10.2337/dc06-1815.

5. Drucker DJ (2003) Enhancing incretin action for the treatment of type 2 diabetes. Diabetes Care 26(10):2929-2940. doi:10.2337/diacare.26.10.2929.

6. Gwaltney SL II, Stafford JA (2005) Inhibitors of dipeptidyl peptidase 4. Annu Rep Med Chem 40:149-165

7. Havale SH, Pal M (2009) Medicinal chemistry approaches to the inhibition of dipeptidyl peptidase- 4 for the treatment of type 2 diabetes. Bioorg Med Chem 17(5):1783-1802. doi:10.1016/j.bmc.2009.01.061.

8. Villhauer EB, Coppola GM, Hughes TE (2001) DPP-IV inhibition and therapeutic potential. Ann Reports Med Chem 36:191-200

9. Weber AE (2004) Dipeptidyl peptidase IV inhibitors for the treatment of diabetes. J Med Chem 47(17):4135-4141. doi:10.1021/jm030628v.

10. Lankas GR, Leiting B, Roy RS, Eiermann GJ, Beconi MG, Biftu T, Chan CC, Edmondson S, Feeney WP, He H, Ippolito DE, Kim D, Lyons KA, Ok HO, Patel RA, Petrov AN, Pryor KA, Qian X, Reigle L, Woods A, Wu JK, Zaller D, Zhang X, Zhu L, Weber AE, Thornberry N (2005) Dipeptidyl peptidase IV inhibition for the treatment of type 2 diabetes: potential importance of selectivity over dipeptidyl peptidases 8 and 9. Diabetes 54(10):2988-2994. doi:10.2337/diabetes.54.10.2988

11. Šedo A, Malik R (2001) Dipeptidyl peptidase IV-like molecules: homologous proteins or homologous activities? Biochim Biophys Acta 1550:107-116. doi:10.1016/S0167-4838(01)00278-3.

12. Ahre'n B, Simonsson $E$, Larsson $H$, Landin-Olsson $M$, Torgeirsson $H$, Jansson P-A, Sandqvist M, Bavenholm P, Efendic S, Eriksson JW, Dickinson S, Holmes D (2002) Inhibition of dipeptidyl peptidase IV improves metabolic control over a 4-week study period in type 2 diabetes. Diabetes Care 25(5):869-875. doi:10.2337/diacare.25.5.869.

13. Ahre'n B, Gomis R, Standl E, Mills D, Schweizer A (2004) Twelve- and 52week efficacy of the dipeptidyl peptidase IV inhibitor LAF237 in metformin- 
treated patients with type 2 diabetes. Diabetes Care 27(12):2874-2880. doi:10.2337/diacare.27.12.2874.

14. Tsu H, Chen X, Chen CT, Lee SJ, Chang CN, Kao KH, Coumar MS, Yeh YT, Chien $\mathrm{CH}$, Wang HS, Lin KT, Chang YY, Wu SH, Chen YS, Lu IL, Wu SY, Tsai TY, Chen WC, Hsieh HP, Chao YS, Jiaang WT (2006) 2-[3-[2-[(2S)-2Cyano-1-pyrrolidinyl]-2-oxoethylamino]-3-methyl-1-oxobutyl]-1,2,3,4tetrahydroisoquinoline: a potent, selective, and orally bioavailable dipeptidederived inhibitor of dipeptidyl peptidase IV. J Med Chem 49(1):373-380. doi:10.1021/jm0507781.

15. Kakigami T, Oka M, Katoh N, Yoshida M, Shirai M, Murase T, Sakairi M, Yamamoto T, Takeuchi M, Hayashi Y, Takeda M, Makino M (2004)

Compound inhibiting dideptidyl peptidase IV. Chem Abstr 141:190794. W004/067509

doi:10.1186/2191-2858-1-7

Cite this article as: Kato et al:: Synthesis and pharmacological

characterization of potent, selective, and orally bioavailable isoindoline class dipeptidyl peptidase IV inhibitors. Organic and Medicinal Chemistry Letters 2011 1:7.

\section{Submit your manuscript to a SpringerOpen ${ }^{\circ}$ journal and benefit from:}

- Convenient online submission

- Rigorous peer review

- Immediate publication on acceptance

- Open access: articles freely available online

- High visibility within the field

- Retaining the copyright to your article

Submit your next manuscript at $>$ springeropen.com 